\title{
Surgical Approach for Repair of Rectovaginal Fistula by Modified Martius Flap
}

\author{
Sanierung einer rektovaginalen Fistel mittels modifiziertem Martius-Lappen
}

Authors

Affiliations
M. Reichert ${ }^{1 *}$, T. Schwandner ${ }^{1 *}$, A. Hecker ${ }^{1}$, A. Behnk ${ }^{2}$, E. Baumgart-Vogt ${ }^{3}$, F. Wagenlehner ${ }^{4}$, W. Padberg ${ }^{1}$

${ }^{1}$ Department of General and Thoracic Surgery, University Hospital of Giessen, Giessen

${ }^{2}$ Department of Gynaecology and Obstetrics, University Hospital of Giessen, Giessen

${ }^{3}$ Institute for Anatomy, Justus-Liebig-University, Giessen

${ }^{4}$ Department of Urology, University Hospital of Giessen, Giessen
Key words

- birth trauma

- delivery

- gynecology

Schlüsselwörter

- Frauenheilkunde

- Geburtstrauma

- Stuhlinkontinenz

\section{received 28.7.2014 \\ revised $\quad 8.9 .2014$ \\ accepted 15.9.2014}

Bibliography

Dol http://dx.doi.org/

10.1055/s-0034-1383149

Geburtsh Frauenheilk 2014; 74:

923-927 @ Georg Thieme

Verlag KG Stuttgart · New York .

ISSN 0016-5751

\section{Correspondence}

\section{Martin Reichert, MD}

University Hospital of Giessen

Department for General

and Thoracic Surgery

Rudolf-Buchheim-Str. 7

35392 Giessen

martin.reichert@

chiru.med.uni-giessen.de

\section{Abstract \\ $\nabla$}

Rectovaginal fistulas (RVF) are rare but represent a challenge for both patients and surgeons. The most common cause of RVF is obstetric trauma, and treatment is based on fistula classification and localization of the fistula in relation to the vagina and rectum. Conventional therapy frequently fails, making surgery the most viable approach for fistula repair. One surgical procedure which offers adequate repair of lower and middle rectovaginal fistulas consists of interposition of a bulbocavernosus fat flap also called modified Martius flap. First described by Heinrich Martius in 1928, this approach has been continuously modified and adjusted over time and is used in the repair of various pelvic floor disorders. Overall success rates reported in the literature of the interposition of a Martius flap as an adjunct procedure in the surgical management of RVF are 65$100 \%$. We present a detailed description of the operation technique together with a discussion of the use of a dorsal-flapped modified Martius flap in the treatment of RVF.

\begin{tabular}{ll}
\hline Abbreviations \\
$\nabla$ & \\
RVF & rectovaginal fistula \\
MR & magnetic resonance tomography \\
CT & computer tomography \\
ES & endosonography
\end{tabular}

\section{Introduction}

\section{$\nabla$}

Rectovaginal fistula (RVF) are rare diseases. The most common cause of RVF is obstetric trauma, with traumatic devascularization of the perineal region resulting in the development of RVF. Treatment of RVF requires a multidisciplinary approach involving colorectal surgeons, urologists

\section{Zusammenfassung \\ $\nabla$}

Rektovaginale Fisteln sind seltene, aber sowohl für die Patientinnen als auch für die behandelnden Ärzte herausfordernde Erkrankungen. Der häufigste Grund zur Entwicklung einer rektovaginalen Fistel ist das perineale Geburtstrauma, wobei sich die Therapie nach der Einteilung und der Lokalisation der Fistel in Bezug zu Vagina und Rektum richtet. Da die konservative Therapie meist insuffizient ist, muss in den meisten Fällen eine operative Sanierung durchgeführt werden. Eine Möglichkeit dazu stellt die Interposition gesunden Gewebes durch einen bulbokavernösen Fett- bzw. modifizierten Martius-Lappen dar, der 1928 durch Heinrich Martius erstbeschrieben wurde. Zusammen mit einem primären Fistelverschluss sind hohe Erfolgsraten von $65-100 \%$ in der Literatur beschrieben. In dieser Literaturübersicht zur Sanierung rektovaginaler Fisteln mittels modifiziertem Martius-Lappen wird die Operationstechnik anhand der Fallbeschreibung einer Patientin mit komplizierter rezidivierender rektovaginaler Fistel detailliert beschrieben.

and gynecologists. Various approaches are used, depending on the localization, size and etiology of the RVF. Closure of the fistula with interposition of a pedicled tissue flap (of fat or muscle) is a useful surgical approach to reconstruct the perineal space and provide neovascularization. One approach for the repair of rectovaginal fistula in the lower and middle third of the vagina is the modified Martius procedure.

This surgical approach for RVF repair is described here in detail, together with our own results after modified Martius procedure.

\footnotetext{
* Both authors contributed equally to this article.
} 


\section{Rectovaginal Fistula - Etiology}

$\nabla$

Rectovaginal fistulas (RVF) are epithelialized connections between the intestine and vagina; they account for nearly $5 \%$ of all anorectal fistula [1]. Around $88 \%$ of RVF are caused by obstetric trauma with disruption of the rectovaginal septum. $0.1 \%$ of patients who required an episiotomy during vaginal delivery go on to develop RVF [2]. Older publications describe a higher incidence of obstetric trauma, as reflected in a current study by Brown and colleagues who discuss the decrease in RVF repair in the United States $[3,4]$. The incidence of postpartum trauma and RVF, especially complex RVF, is notably higher in third world countries, due to the poor quality of the available medical care and the extent of sexual violence [3].

In addition to obstetric trauma, other causes of RVF are colorectal and pelvic surgery (in up to $10 \%$ of cases in rectal surgery, especially with the use of staplers, neoadjuvant and adjuvant radiochemotherapy increasing the rate), irradiation causing obliterating endarteritis with devascularization of the perineal region, malignant disease (e.g., rectal, vaginal and bladder carcinoma involving direct invasion), local inflammatory processes, diverticulitis, chronic inflammatory bowel disease (about $0.2-2.1 \%$ of all RVF $[3,5])$, and congenital RVF [6,7]. Perineal trauma can also result in RVF [8]. As the cause of RVF in many cases is obstetric trauma, postpartum RVF are frequently associated with sphincter lesions, and sphincter reconstruction is routinely performed during the same operation [9].

\section{Rectovaginal Fistula - Symptoms and Diagnosis $\nabla$}

While the diagnosis can often be easily confirmed by distal examination of the rectum, treatment, especially of recurrent fistula, makes this disorder very complex. Small fistula can be asymptomatic. The progress of RVF is accompanied by severe clinical manifestations: loss of gas and feces from the vagina, diarrhea, tenesmus, frequent urination, abdominal cramps, rectal bleeding, back pain or anorectal burning sensation [2]. In about $90 \%$ of cases, the patient's medical history together with a clinical examination including proctoscopy and vaginal exploration lead to the diagnosis of RVF [10]. If the diagnosis remains unclear, no fistula is found, or malignant disease as the cause of fistula cannot be excluded, the next diagnostic step is imaging using magnetic resonance tomography (MR), computer tomography (CT), colon contrast study or endosonography (ES). MR and ES have the highest diagnostic value for colorectal fistula and additionally allow potential sphincter lesions to be evaluated $[8,11,12]$. CT with rectal contrast filling is the second choice, although CT is very accurate in diagnosing abscess formations or malignancies as complicating comorbidities of RVF [13]. The advantage of ES is its availability and the fact that it offers the option of evaluating sphincter lesions, which are important when choosing the surgical procedure $[11,14]$.

\section{Rectovaginal Fistula - Classification \\ $\nabla$}

Rothenberger et al. differentiated RVF into simple and complex RVF as follows [15]:

1. Simple RVF are located in the lower and middle-third of the vagina; their diameter is less than $2.5 \mathrm{~cm}$ and they are typically caused by trauma or infection.
2. Complex RVF are located in the upper third of the vagina, have a diameter of more than $2.5 \mathrm{~cm}$ and are caused by inflammatory bowel disease (Crohn's disease), irradiation or malignancy [15].

In addition, Fry et al. categorized perineal injuries as injuries with or without fistula and differentiated the vaginal location by classifying perineal damage into five subgroups as follows [16]:

I. perineal injury without fistula

II. perineal injury with fistula in the lower third of the vagina

III. no perineal injury, but fistula in the lower third of the vagina

IV. no perineal injury, but fistula in the middle third of the vagina

V. no perineal injury, but fistula in the upper third of the vagina [16]

\section{Rectovaginal Fistula - Treatment}

$\nabla$

While there are many therapeutic approaches for RVF, they depend on the fistula's localization and the patient's comorbidities. Lower RVF are usually reconstructed using an anal, perineal or vaginal approach. Transabdominal approaches are used for the repair of higher fistulas [3]. Anatomic fistula repair alone is associated with lower success rates compared to combined procedures with the adjunctive interposition of healthy, vascularized tissue [17]. In most therapeutic approaches healthy tissue is transposed into the perineal space between the rectal and vaginal layer to enhance blood supply and granulation tissue, obliterate "dead" space, protect the sutures of anatomic fistula repair of the different layers, and prevent rectal and vaginal stenosis. The rate of spontaneous healing is low, making it important to ensure that RVF repair is adequate, as the success rate decreases with the number of prior operations $[18,19]$.

\section{Martius Flap \\ $\nabla$}

The Martius procedure for the surgical repair of urethrovaginal fistula was first described by Heinrich Martius in 1928. He used the bulbocavernosus/bulbospongiosus muscle for reconstruction [20]. Over time, the Martius flap was modified and became a more extensive procedure, which used a vascularized adipose tissue flap from the labium majus between the bulbospongiosus and ischiocavernosus muscle with or without the muscle. The Martius procedure and its modifications are also used for extraperitoneal repair of fistula in the perineal region, either urogynecological [21-23] or rectovaginal fistula [7,24-27], as well as to treat stress urinary incontinence by lifting the bladder neck [28], in tethered vagina syndromes, rectal strictures, or vaginal stenosis [22].

Our cadaveric dissections showed that the pedicled flap of the modified Martius procedure is composed of fibroadipose tissue from the interspace between the bulbocavernosus and ischiocavernosus muscle which receives its blood supply latero-ventrally from external pudendal artery branches and latero-dorsally from internal pudendal artery branches ( $\bullet$ Fig. 4). The modified Martius procedure for urogynecological indications (e.g. for vesicovaginal fistulas) uses an anterior vascular pedicle, while Martius procedures for colorectal indications (including RVF repair) use a posterior vascular pedicle what allows rotation either forwards or backwards depending on the indication of surgery [22]. 


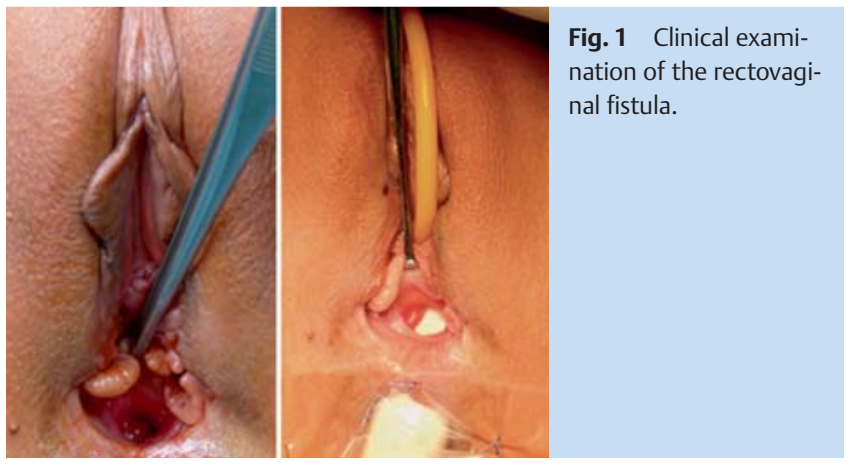

In their retrospective analysis, Pinto et al. described an overall success rate of $87 \%$ after a follow-up of 20 months for fistulas treated with one or more surgical procedures. Depending on the underlying disease, they described success rates of $66 \%$ if the fistula was caused by obstetric trauma, 70\% if it developed postoperatively and 44\% for RVF caused by Crohn's disease [29]. The literature reports overall success rates of $33-100 \%$ for the Martius procedure in the surgical repair of mainly recurrent RVF [3, 30]. The majority of studies in the current literature consist of small retrospective analyses or case series. In the German guidelines for the treatment of RVF, Ommer et al. reviewed the studies dealing with the Martius procedure for RVF repair. Only seven of the cited studies analyzed more than 10 patients; they reported primary healing rates of 65\% (patients with Crohn's disease) and of $75 \%$ (patients without Crohn's disease) to 100\% [3]. Most studies reported high healing rates with this procedure, indicating that the (modified) Martius flap can be recommended for the surgical management of complicated and recurrent RVF [3].

\section{Modified Martius Flap - Operative Technique}

To keep the operative site clean, a temporary transurethral urinary catheter is placed preoperatively ( Fig. 1 shows the preoperative examination). The patient is placed in a modified lithotomy position and the first incision is made horizontally in the perineal region to dissect the posterior vaginal wall from the rectum and mobilize the rectovaginal fascia. The next step consists of repairing the rectal mucosa using single 3-0 PDS sutures ( Fig. 3). In cases with anorectal sphincter involvement, the sphincter muscles should be repaired by sphincteroplasty, using an end-to-end or overlapping suture technique as previously described to prevent incontinence [31].

After the rectal defect is proven to be repaired, the exact localization where the modified Martius flap will be dissected from the labia majora area is measured $(6 \mathrm{~cm}$ from the perineum, 45 degrees in an anterior-cranial direction and $8 \mathrm{~cm}$ cranially; - Fig. 3). A second, 8-cm vertical incision is made at this site ( Fig. 3) and the vascular pedicled flap of adipose tissue is prepared from anteromedial to posterolateral ( $\mathbf{F i g}$. 3) with careful preservation of the small dorsolateral arteries ( Fig. 4). As mentioned above, the fibroadipose tissue creating the modified Martius flap receives its blood supply from a small vascular branch network derived anterolaterally from the external pudendal artery and posterolaterally from the internal pudendal artery ( Fig. 4). In the repair of RVF it is important to use the posterolateral internal pudendal artery for the vascular pedicle to ensure

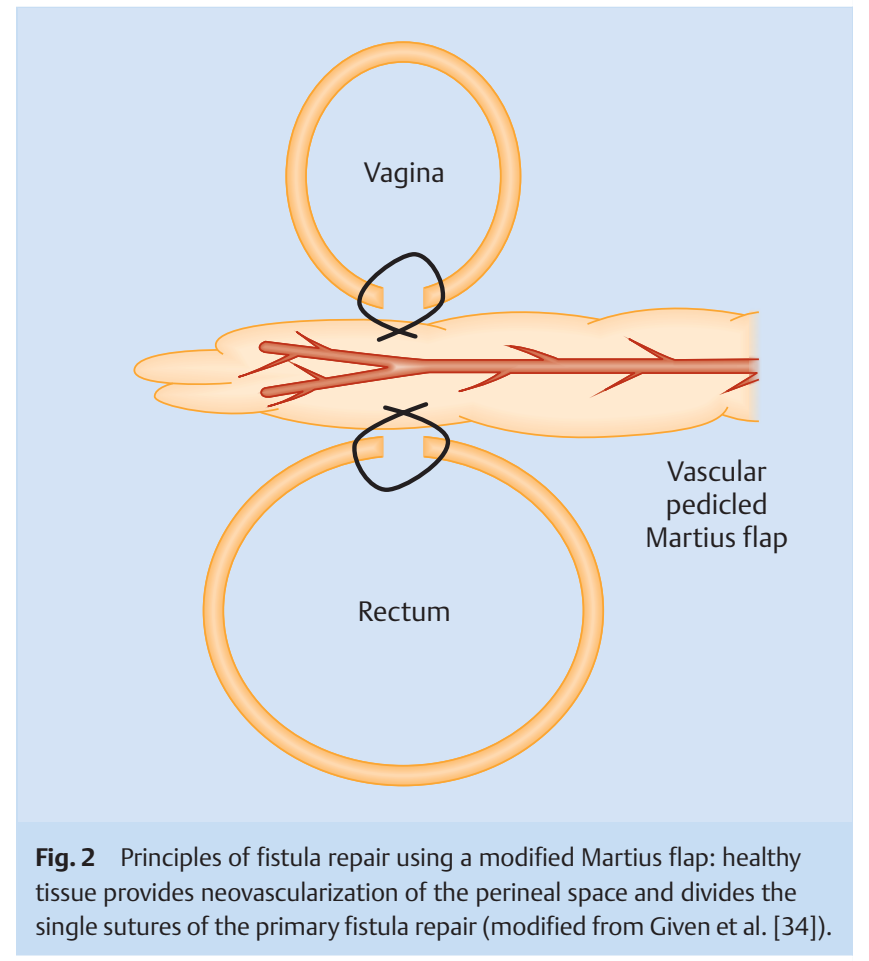

sufficient flap length to reach dorsally into the spatium rectovaginale.

After dissection and mobilization of the vascular pedicled modified Martius flap, the flap must be placed in the spatium rectovaginale. From the perineal incision a subcutaneous tunnel is prepared under the bulbospongiosus muscle close to the ramus descendens of the pubic bone so that the flap can be inserted between the vagina and rectum to fill up the "dead" space, achieve neovascularization of the perineal region, and separate the sutures of anatomic fistula repair to achieve optimal wound healing ( Fig. 2). The vascular pedicled flap should be handled with care; rotation or twisting should be avoided during transposition to ensure optimal blood supply. The adipose tissue flap is fixed to the external surface of the anal sphincter with single tension-free 3-0 PDS sutures, followed by hemostasis control and wound closure using single 3-0 Prolene sutures ( $\bullet$ Fig. 3). Wound closure must be gentle to allow uncomplicated drainage of postoperative seroma to guard against infection ( $\bullet$ Fig. 3 ).

As a diverting colostomy is an appropriate method to prevent infectious complications in the perineal region which can impair wound healing, especially in the management of recurrent RVF, a temporary transversostomy is done during the same session in addition to RVF repair $[17,29]$.

\section{Case Report}

A 32-year-old patient suffered from complex persistent and therapy-resistant RVF (diameter approximately $3 \mathrm{~cm}$; $\bullet$ Fig. 1). Traumatic vaginal delivery in 2009 led to perineal injury with subsequent development of a RVF, degree II according to Fry's classification. Initial management consisted of surgery with insertion of a fistula plug and plastic reconstruction of the posterior vaginal wall. Three months after initial surgery the fistula persisted, and 

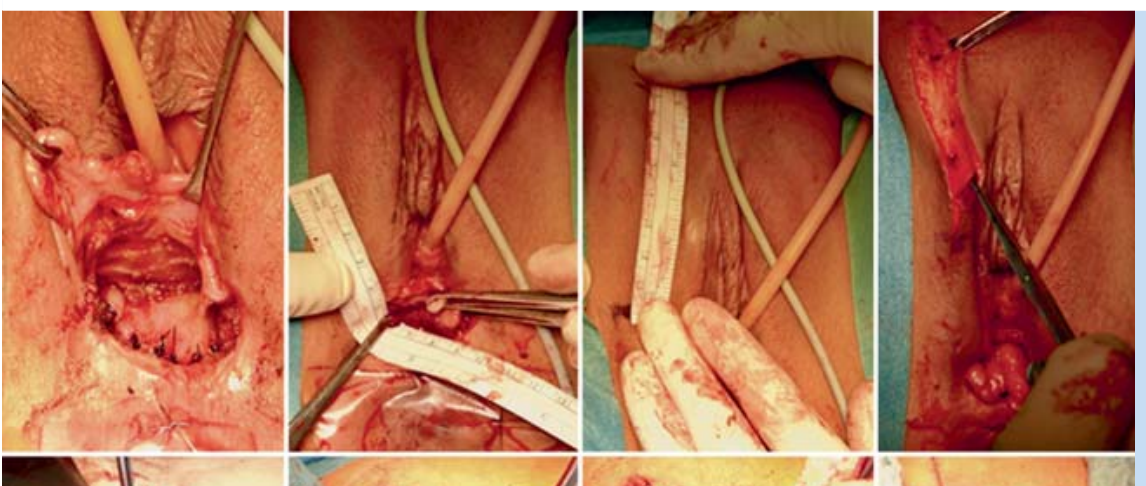

Fig. 3 Operative technique. After a horizontal perineal incision, the spatium rectovaginale is mobilized, the fistula is dissected, and the posterior vaginal wall and rectal mucosa are closed with single sutures. Only one operating field is used for RVF repair in the Martius procedure. After precise measurement $(6 \mathrm{~cm}$ from the perineum, 45 degrees in an anterior-cranial direction and $8 \mathrm{~cm}$ cranially), the second vertical labia majora incision is made to dissect the posterior pedicled adipose tissue flap. The modified Martius flap is then pivoted dorsally under the ischiocavernosus muscle and sutured without tension in the spatium rectovaginale to separate vaginal and rectal sutures.

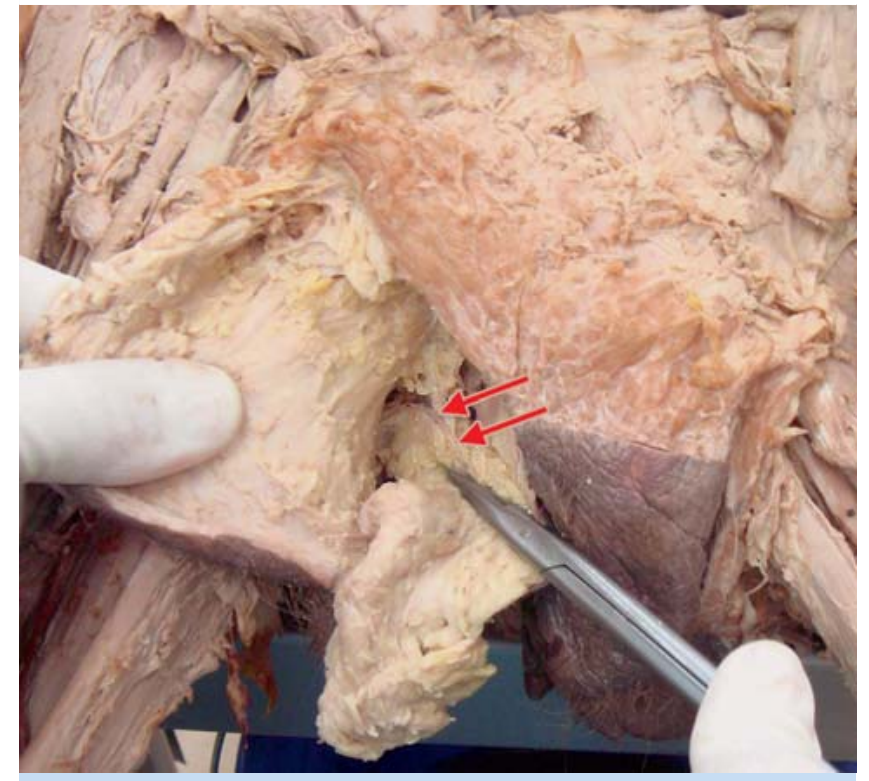

Fig. 4 Cadaveric studies of the blood supply of a pedicled Martius flap. Arrows indicating small dorsal blood supply, derived from the internal pudendal artery. the surgical procedure was repeated. After a further nine months RVF still persisted, and surgery was again performed with plastic reconstruction of the posterior vaginal wall together with interposition of a rectal mucosal flap and interposition of a bioprosthetic mesh (SURGISIS ${ }^{\circledR}$ mesh) into the rectovaginal space [32], but this did not prevent the patient from again developing RVF. Forty-eight months after the initial obstetric trauma and persistent RVF, the patient underwent surgery with a modified Martius approach as described above. The procedure was carried out by an interdisciplinary team of general surgeons and urologists in a pelvic floor center. Operation time was 132 minutes for fistula re- pair and creation of a diverting transversostomy. No intraoperative or postoperative complications were noted according to the Clavien-Dindo classification [33]. Both perineal and pudendal wounds healed per primam, no perineal sepsis or wound infection was observed, and the temporary transversostomy was removed four months after RVF repair. No recurrence of RVF was observed at a follow-up of 15 months. The functional and cosmetic results were excellent with high patient satisfaction and greatly improved quality of life.

\section{Conclusion}

$\nabla$

The Martius procedure for RVF repair is limited to a single operating field. It is a safely feasible procedure which offers good cosmetic and functional results by enhancing blood supply in the perineal region. RVF repair should not be performed in inflamed tissue, so a diverting transversostomy should be considered to prevent perineal sepsis, depending on the etiology of RVF and local conditions. A diverting colostomy can be performed together with the Martius procedure in the same session.

Martius procedure for RVF repair offers the additional benefit of dividing vaginal and rectal layers after suturing and improves wound healing through neovascularization. It can be safely performed with good postoperative results, even for the repair of complex fistula which have been treated surgically multiple times previously. Long-term follow-up of our patient indicates a low recurrence rate of RVF after repair using a Martius approach together with a temporary transversostomy and that patients benefit from the good functional and cosmetic results and a dramatically improved quality of life.

\section{Consent}

Informed consent was obtained from the patient and is available for review from the editor of this journal. 


\section{Conflict of Interest}

\section{$\nabla$}

Thilo Schwandner has a flying doctor contract with the Ethicon company for STARR and TRANSTARR operations (constipation). Thilo Schwandner receives honoraria for lectures on coloproctology from the Ethicon company and Medtronic as well as for lectures on fistula surgery from the Cook company. Florian Wagenlehner is in the advisory board of Serag-Wiessner GmbH \& Co. KG; the other authors declare no conflict of interest and that no funding was received for this article.

\section{References}

1 Tsang $C B$, Rothenberger $D A$. Rectovaginal fistulas. Therapeutic options. Surg Clin North Am 1997; 77: 95-114

2 Homsi R, Daikoku NH, Littlejohn J et al. Episiotomy: risks of dehiscence and rectovaginal fistula. Obstet Gynecol Surv 1994; 49: 803-808

3 Ommer A, Herold A, Berg E et al. German S3-Guideline: rectovaginal fistula. Ger Med Sci 2012; 10: Doc15

4 Brown HW, Wang L, Bunker $\mathrm{CH}$ et al. Lower reproductive tract fistula repairs in inpatient US women, 1979-2006. Int Urogynecol J 2012; 23: $403-410$

5 Saclarides TJ. Rectovaginal fistula. Surg Clin North Am 2002; 82: $1261-$ 1272

6 Lindner H, Kiesel L, Woitek G. [Isolated occurrence of a congenital rectovaginal fistula in a girl]. Zentralbl Chir 1988; 113: 1580-1582

7 White AJ, Buchsbaum HJ, Blythe JG et al. Use of the bulbocavernosus muscle (Martius procedure) for repair of radiation-induced rectovaginal fistulas. Obstet Gynecol 1982; 60: 114-118

8 Stoker J, Rociu E, Schouten WR et al. Anovaginal and rectovaginal fistulas: endoluminal sonography versus endoluminal MR imaging. AJR Am J Roentgenol 2002; 178: 737-741

9 Delancey JO, Berger MB. Surgical approaches to postobstetrical perineal body defects (rectovaginal fistula and chronic third and fourth-degree lacerations). Clin Obstet Gynecol 2010; 53: 134-144

10 Kropil F, Raffel A, Renter MA et al. [Individualised and differentiated treatment of rectovaginal fistula]. Zentralbl Chir 2010; 135: 307-311

11 Stoker J, Rociu E, Wiersma TG et al. Imaging of anorectal disease. Br J Surg 2000; 87: 10-27

12 Schmidt S, Chevallier P, Bessoud B et al. Diagnostic performance of MRI for detection of intestinal fistulas in patients with complicated inflammatory bowel conditions. Eur Radiol 2007; 17: 2957-2963

13 Kuhlman JE, Fishman EK. CT evaluation of enterovaginal and vesicovaginal fistulas. J Comput Assist Tomogr 1990; 14: 390-394

14 Sudol-Szopinska I, Jakubowski W, Szczepkowski M. Contrast-enhanced endosonography for the diagnosis of anal and anovaginal fistulas. J Clin Ultrasound 2002; 30: 145-150

15 Rothenberger DA, Goldberg SM. The management of rectovaginal fistulae. Surg Clin North Am 1983; 63: 61-79
16 Fry RD, Kodner IJ. Rectovaginal fistula. Surg Annu 1995; 27: 113-131

17 Songne K, Scotte M, Lubrano J et al. Treatment of anovaginal or rectovaginal fistulas with modified Martius graft. Colorectal Dis 2007; 9: 653656

18 Lowry AC, Thorson AG, Rothenberger DA et al. Repair of simple rectovaginal fistulas. Influence of previous repairs. Dis Colon Rectum 1988; 31: 676-678

19 Reisenauer C, Huebner M, Wallwiener D. The repair of rectovaginal fistulas using a bulbocavernosus muscle-fat flap. Arch Gynecol Obstet 2009; 279: 919-922

20 Sajjadi SG, Hortváth ÖP, Kalmár K. Martius flap: historical and anatomical considerations. Eur J Plast Surg 2012; 35: 711-716

21 Angioli R, Penalver M, Muzii L et al. Guidelines of how to manage vesicovaginal fistula. Crit Rev Oncol Hematol 2003; 48: 295-304

22 Elkins TE, DeLancey JO, McGuire EJ. The use of modified Martius graft as an adjunctive technique in vesicovaginal and rectovaginal fistula repair. Obstet Gynecol 1990; 75: 727-733

23 Rangnekar NP, Imdad Ali N, Kaul SA et al. Role of the Martius procedure in the management of urinary-vaginal fistulas. J Am Coll Surg 2000; 191: 259-263

24 McNevin MS, Lee PY, Bax TW. Martius flap: an adjunct for repair of complex, low rectovaginal fistula. Am J Surg 2007; 193: 597-599; discussion 599

25 Pinedo G, Phillips R. Labial fat pad grafts (modified Martius graft) in complex perianal fistulas. Ann R Coll Surg Engl 1998; 80: 410-412

26 Rivadeneira DE, Ruffo B, Amrani $S$ et al. Rectovaginal fistulas: current surgical management. Clin Colon Rectal Surg 2007; 20: 96-101

27 Pitel S, Lefevre JH, Parc Y et al. Martius advancement flap for low rectovaginal fistula: short- and long-term results. Colorectal Dis 2011; 13: e112-e115

28 Shaw W. The Martius bulbo-cavernosus interposition operation. $\mathrm{Br}$ Med J 1949; 2: 1261-1264

29 Pinto RA, Peterson TV, Shawki S et al. Are there predictors of outcome following rectovaginal fistula repair? Dis Colon Rectum 2010; 53: $1240-1247$

30 Kin C, Gurland B, Zutshi M et al. Martius flap repair for complex rectovaginal fistula. Pol Przegl Chir 2012; 84: 601-604

31 Aigmueller T, Umek W, Elenskaia K et al. Guidelines for the management of third and fourth degree perineal tears after vaginal birth from the Austrian Urogynecology Working Group. Int Urogynecol J 2013; 24: 553-558

32 Schwandner O, Fuerst A, Kunstreich K et al. Innovative technique for the closure of rectovaginal fistula using Surgisis mesh. Tech Coloproctol 2009; 13: 135-140

33 Dindo D, Demartines N, Clavien PA. Classification of surgical complications: a new proposal with evaluation in a cohort of 6336 patients and results of a survey. Ann Surg 2004; 240: 205-213

34 Given FT jr., Acosta AA. The Martius procedure-bulbocavernosus fat flap: a review. Obstet Gynecol Surv 1990; 45: 34-40 